\title{
「情報管理」創刊30 巻記念企画
}

\section{座 談 会}

\section{0 年後Ф情辂社会を察。 いま，何をなす心゙きか}

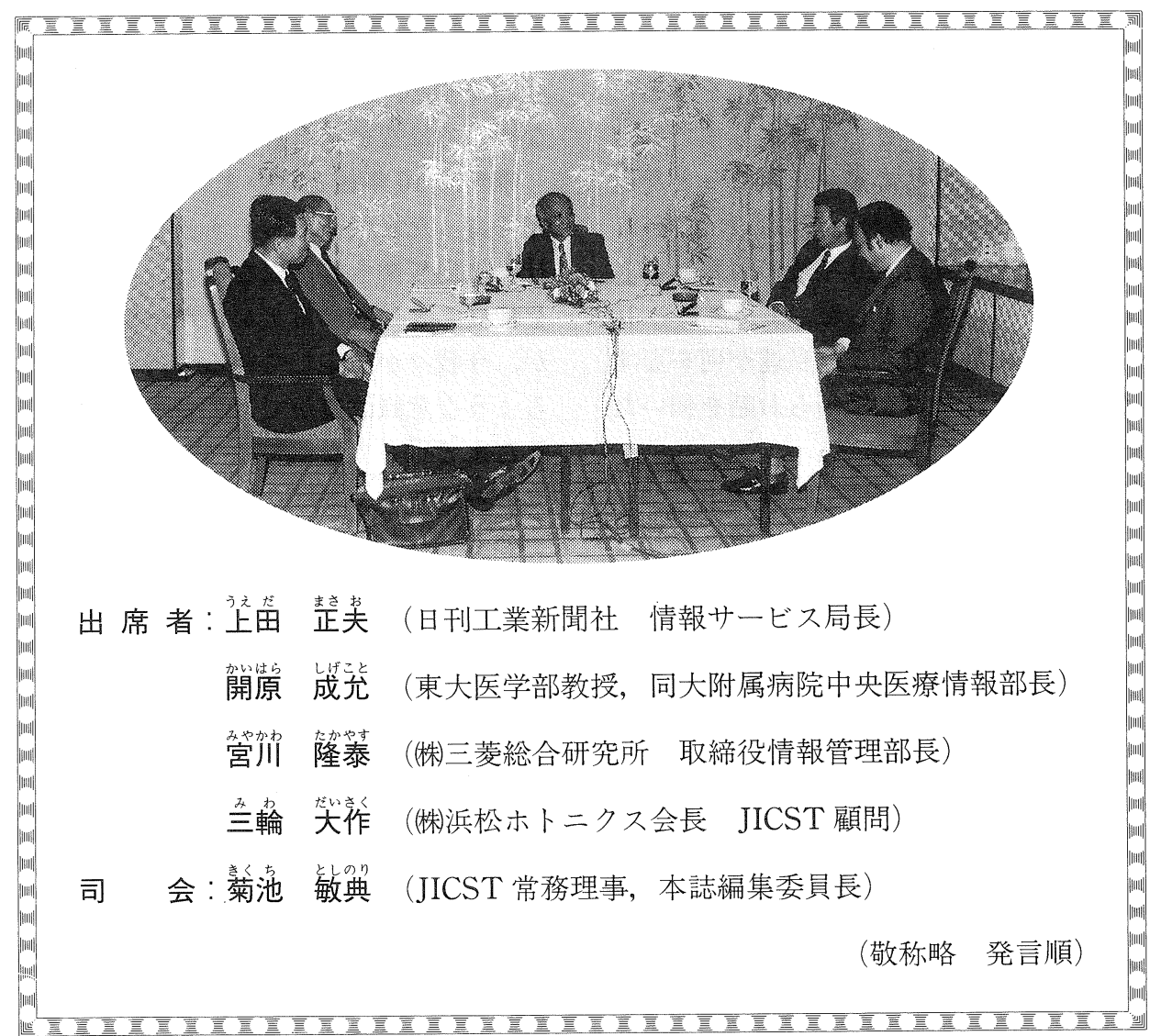

昭和 62 年 10 月 30 日(金) 東京永田町のキャピトル東急ホテルにて収録。 


\section{は じめに}

菊池 敏典 本日は皆様方, お忙がしいところ お集まりいただき，大変ありがとうございます。 ご承知のように, JICST はことしでちょうど設立 30 周年を迎えましたが、『情報管理』誌も昭和 33 年 1 月に創刊して 30 巻になりました。

創刊当時は『月刊 JICST』という誌名で，JICST の機関誌という一面导持った，情報のもろもろの 啓蒙・普及をねらいとして出発しました。それか ら 30 年の間に, 世の中の変化につれて誌名を『情 報管理』と変え, 誌面もさまざまに変遷して, 今 日に至っております。

そこで本誌の 30 巻記念の企画としまして, 座談 会を計画致しました。初めは「21世紀」を考えた のですが,「21世紀」というテーマはもうすでにい ろいろな所で語られておりますから，もっと身近 な，現在情報関係の仕事に携わっておられる方に， より密接なお話しをと考え「10 年後の情報社会」 を取り上げることにいたしました。また，その 10 年後のあるべき姿に対して，今，私達が何をなす べきなのか，それぞれのお立場からお話を伺いた いと思います。

まずはじめにそれぞれの方に「10 年後」につい てお話しいただき，その後は司会は遠慮いたしま して，今，何をなすべきなのかをざっくばらんに お話しいただこうと考えております。

それでは，1番バッターとして日刊工業新聞の 上田さんです。上田さんはずっと新聞記者として 第一線でご活躍され，今はNK-MEDIA という データベースを作る立場の責任者でいらっしゃい ますので，ジャ一ナリストの厳しい目で見て，今 後の情報はいったいどうなるのかという話題提供 も含めて，お話しいただきたいと思います。

\section{人の意識や社会慣習の变革が必要}

上田 正夫 「10 年後」というといちばん話し 難いところですね。21 世紀だったら適当に夢を話 せばいいし，2，3 年後ならもうだいたい子測がつ
きますから，話しやすいのでしょうが。

いろいろ考えてみて, 私はたぶん 10 年後の情報 社会で使われているシステムとかハードは，すで に今現在あるものが，もっと使いやすくなって実 用化されているだろうと思います。ですから，そ ういう点で見れば今とそれほどまだ大きく変わっ てないんじやないかという気がします。

それからもう一つ, ソフトやハードのように人 間の知恵で開発できるものはかなり進むんでしょ うが，それを受け取る人間の意識ははたして変わ っているのか変わっていないのか，その辺で私自 身あんまりはっきりしたことが言えないんです。 やはり情報化社会では人間の意識なり社会の慣習 なりがそれに対応して相当変わる必要があると思 うんですが，10 年後ではそれほど大きく変わって ないのではないかと思います。

確かに 10 年後といいますと,今テレビゲームな どで育った世代が，ちょうど 20 代，30 代になり， 社会に出て働き盛りになるわけですから，ハード を使うことに対するアレルギーは少ないでしょう が，今我々が想定しているものを全部使いこなせ るような意識改造ができているかというと，まだ そこまで行ってないのではないか，その次の世代 ぐらいになるのではないか。そう思っています。

そういった中で大いに変わらなきやいけないの が多分新聞産業だろうと思います。新聞産業とい うのは，データベースを作るとか，情報の二次加 工で文字放送に乗り出すとか, ニューメディアみ たいなことをやっていますが，新聞本体はまだほ とんど変わっていない。しかし，新聞の形態は 10 年後に今と同じなのかどうか。ほかのメディアが 発達するにつれて今の新聞の形は非常に変わって くるのではないか。変わらざるを得ないのではな いか。もし変わらないとすると，新聞産業の将来 は暗くなってしまうでしょう。

もっと具体的にいえば，大は「朝日」「読売」「毎 日」というふうな新聞から小は我々の新聞まで含 めて，結局マスコミというくくり方で新聞をつく っているわけですが，いろいろなメディアが出て くると，きっと今のような形の新聞は成り立たな 
くなって，朝・夕刊はもちろん別にした方がいい でしょうし，もっともっと経済とか政治とか，細 分化された形にならざるを得ないのではないかと 思います。

菊池ありがとうございました。それでは次に 開原先生ですが, 先生は特に医学・医療関係の情報 の分野で，国内のみならず国際的にも幅広く活躍 されておられますが，10 年後と言われて開原先生 はどういうことを考えられますか。

\section{医療の世界は情報社会の一つのモデル}

開原 成允 私は医療畑にいるものですから， 医療の目で物を考えることが多いんです。医療の 世界はちょっと特殊なようですが，ある意味では 社会の一つのモデルだという見方もできます。そ うすると意外におもしろい面もあります。という のは，医療の世界で生きている人間というのは医 者とか看護婦ですが，彼らは一応の知的水準を持 つていますから，何か新しいものが出てくると， それに対して好奇心で使っていこうという気持ち と，どうもけしからんものが入ってきたという気 持ちがある。これは大体だれでもそうなのでしょ うが，医療社会では，その反応が割に先鋭的なあ るいはクリアな格好で出てくるものですから，そ の中で実際に起こっていることが後の世の中を占 うために，役に立つことがあるんではないかとい う気がします。

そんな目で医療を眺めてみると，二つの見方が あります。一つはどんどん医学が進んで新しい医 療をやるために新しい情報が必要になってくる。 それを手に入れやすい環境が情報社会によってで きてくる。それによってどんどん医療はよくなっ てくる。それはデータベースであってもいいし， もうちよっと知識べースで的なものであってもい いし，ニューメディアであってもいい。そjいう いろんな情報提供のシステムや産業が栄えること によって医療がよくなってくる。今までの図書館 は，図書をおく所というイメージがなくなって， 図書館自体が医療の中に浸透してくるような形に
なってくる，という明るい見方です。たぶんそう なるだろうと思います。今も大きな病院では, 病 棟, ナースステーションなどに端末がかなり普及 してきていますから，他でもどんどん普及してく るだろうと思います。そういうプラスのイメージ があります。

それからもう一つ，こういう情報社会は何か恐 ろしいものだという気持ちもあるんですね。それ はいろんなところにあるんですが，例えば最近力 ードで病歴を持ち歩くという話があります。今ま で病歴というのは病院に置いてあったんですが, それをICカードとか光カードに入れて患者さん が持って歩くんじやないか。そうなってくると， これはやはりかなり医療そのものに対する大きな 変革の要因になるんではないか。そういうものが 世の中に普及することによって逆に医療機関が系 列化されてくるんではないか。あるいは，いろん な情報システムができることによって医療機関が 連携をうまく保てるのはいいのだが，その連携の 外に置いてきぼりにされた医療機関はもう生きて いけなくなるんではないか。そういう意味で情報 システムに支配された医療の姿になるのではない か。まあ，多少 SF 的な感じもないではないです が，そういう社会的なインパクトが医療の本質に 変革を与えるんじやないか。そういうおそれみた いなものがあります。

今，それらが交錯した気持ちがあって，10 年後 に下手をするとその両方の面が出てくるのではな いかなという感じがいたします。

菊池それでは次に宮川さん，お願いします。 宮川さんは一貫して経済, それから情報関係の研 究機関で活躍され，日本データベース協会の会長 をされていて，データベース関係の日本における 権威者のお一人だと言えると思います。そういう お立場からいかがでしょうか。

\section{過去 10 年よりさらに大きく変化する}

宮川 隆泰 私は守備範囲が経済学でございま すので，情報というのをいつも商売の種になるか 
ならないかという形でしか見ないんです。10年先 の予測はいろんな所でやっていますが,その 10 年 とその前の 10 年の, 同じ 10 年在少!比較してみ たいと思います。これは昭和年劣で、いますと 52 年から 62 年までの間なんですが, 情報サービスと いう面ではやはり非常に変化が大きかった 10 年 だったと思います。

JICSTのサービスのことを考えてもそうです。 昭和 52 年といいますと, JICST の JOIS-I が始ま ってすぐの頃です。私どもは丸の内三菱各社共通 専用端末を三菱本館の地下に置いて，オンライン 検索を始めた。まあアメリカでは，やっていまし たが，日本の国内で，当時まだ専用線でしたし， モデムも高かったので，どうやって費用を負担す るかなんていう議論をした覚えがございます。あ れが最初でした。それで，この 10 年で最初の専用 線から始まって, 公衆回線経由になって, 最初は いわゆる専用端末でしたが，今はもうあらゆるパ ソコンで，いろんなことができるようになった。 それから, サービスの形態も非常に多様化してき まして，我々がアクセスできるデータベースの数 も，幾何級数的にとは申しませんが，急速にふえ た。何倍なんていうもんじゃないですね。

そういうことで，私どもが研究調査をしたり， いろいろ調べるときの情報の収集や事前の準備段 階の作業の中にオンライン情報検索が入ってきた わけで,これの入り方というのは過去 10 年の非常 に大きな変化だったんじゃないかと思います。

それからもう一つ，そのころ議論していたこと で今でも印象的に覚えていることがあります。ワ 一ドプロセッサなるものをアメリカで最初に見せ られたのが 15 年ぐらい前だったと思うんですが, そのときの直感で我が国には日本語という難物が あるから，すぐには導入できないだろうという意 見でした。それで，日本語ワードプロセッサとい うのはどうなるだろうか，どのくらいの速さで普 及するだろうかという議論を研究所の中でやった ことがあるんですが，なかなか時間がかかるだろ うというのがそのときの結論でした。

ところが，一方で技術開発が非常に急速に進み
ましたので，実際の技術の方が早く進んで，日本 語ワードプロセッサの普及は非常に急速に進ん だ。これがオンライン検索の利用を加速化する一 つの条件になった。考えると, 過去 10 年というの は非常に大きい変化，特に日本国内の各分野にお ける電子化された情報の蓄積と利用の面でそうで あったと思います。

それから，私どもの日本データベース協会は昭 和 54 年 12 月に 19 社で, データベース・サービス 業連絡愍談会として発足したのですが，日刊工業 新聞とか日経新聞, 朝日新聞など主要な新聞社, 大きなコンピュータセンターから始まって銀行と か商社とか, 今 106 社のサービス機関が参加して いますが，これも急速に伸びたなあと感じており ます。

これから先の 10 年は, 今までの 10 年の変化が さらに加速化されるのか，それとも非常にモデレ 一トな変化になっていくのか，私はもう少し変化 は大きいんじやないかという感じがしておりま す。いろんな理由が考えられますが，今までの 10 年の変化よりも，もう一つ大きい変化が，少なく ともこの情報化という面では社会的, 経済的にあ りそうだなという印象です。

菊池 宮川さんは最近 10 年間の大きな特徵と してオンラインの問題を一つ挙げられましたが, やはり今後どうなるかということを考える場合, 今までのプロセスを一応大ざっぱにくくっておく こともかなり大事なことだろうと思うんです。 その意味では三輪先輩は昭和 32 年の JICST 設立時には科学技術庁の調査普及局長でいらっし やいましたし，その後昭和 34 年から 42 年まで JICSTの常務理事でした。JICSTの生みの親で ありまた育ての親でもあり，また本誌の初代編集 委員長でもあります。そういうことで 30 年間情報 に関与しておられますので，将来を考えるのに非 常に参考になるのではないかという点とか，ある いは今問題になっていることは昔はこういうプリ ミティブな形でしかなかったとか，そういう主と して今までの経過をお話しいただけたらと思いま す。 


\section{大きく変わる情報の内容と処理}

三輪 大作 情報センターが昭和 32 年にでき た当時は,大きくなってもせいぜい 120 人ぐらい, 10 億円程度の規模だろうという計画を大蔵省に 出した覚えがあるんです。30 年たって，今事業規 模が約 110 億円ですが，これほどになるとはだれ も思っていなかった。今日になってみると，先ほ どお話のあったように最後の 10 年間, つまり JICSTができて 20 年目から 30 年目は大変な又 ピードで発展したわけです。

設立 20 年のときに 10 年後のセンターはどうか ということを書いたものがありますが，それを見 ると 30 万件ぐらいの情報処理だろうということ になっています。それが現在は 55 万件を処理して いるというので，これも見当外れだったことにな ります。飛躍的な発展を遂げたわけですね。

それには，情報をつくる情報員の積み重ねが非 常にエキスパートになったということとか，機械 化の進展などいろいろ理由はあるかと思います が，こういう地道な情報活動というのは急にはな かなかできないものです。今，通産省，厚生省， 農水省など各省がそれぞれ相当本腰を入れて情報 活動をやり始めていますが，中枢機関としてでき た情報センターの 30 年の蓄積, 特に人材あるいは 資料の蓄積を追い越すのは簡単ではありません。 今後 10 年間は, 相当大きい飛躍をするだろうとい うお話がございましたが, あと 10 年たつと予想し ないほど大きくなっているかもしれないし，その 点は非常に楽しみです。

ただ，私は多少 JICSTなどの情報機関の情報 処理の内容が変わってくるんじやないかと思いま す。もちろん機械翻訳なども一部実用化されて能 率がよくなると思いますが，10 年後は日本の国内 で発生する情報の処理が相当子えて，それを読み 直してテープに入れるという仕事が大きいウエー トを占めていくんじやないかと思うんです。とい うのは, 日本の研究者の数あるいは特許出願の数, 発表される論文の数が相当ふえてきているのと同 時に，先般イギリスで会議があって各国から多く
の方が集まったように，日本の情報についての関 心が大変増してきているからです。日本は経済大 国ですから，当然情報だって多いはずなんで，そ の処理という面でJICST は今後一つの, 軌道修 正を迫られるんじゃないかと思っております。

\section{今, 何が求められているのか}

菊池 10 年後を見とおして，ひととおりお話を 伺いましたが，それぞれの問題点によって現在の 状況は異なっておりますし，今後の進め方も違っ てくると思うのですが, そういったことも含めて, これからは順不同でご発言いただきたいと思いま す。

\section{日本情報の所在を示す情報を早く}

宮川 9 月にイギリスで「日本情報に関する国 際会議」というのがございました。BLの主催, JICSTとアメリカのNTISの後援で行われまし たが，私どもも行きましていろいろ議論をしまし た。私はキーノートスピーチをやりました。

JICST は現在は年間 55 万件の処理レコード数 がありますが，そのうちかなりの部分を占める外 国の雑誌論文の処理に，まだかなりの精力を割か れていると思います。この，外国のサイエンス。 テクノロジーの進展状況をウオッチする，モニ夕 一するというのは JICSTの設立の非常に大きな ミッションでしたから，これは当然のことだと思 うんですが，これからは，今三輪先生がおっしや いましたように，我が国で発生する膨大な量の情 報の外国へのディッセミネーションが非常に大き な任務になると思います。例えばChemical Abstractsだとか MEDLARSだとか BIOSISだと かINSPECなど, 外国のデータベースに入ってい るデータについては何も JICST で重複して入力 する必要はないということに，次第になってくる んじやないかと思います。

JICSTも今度の国際会議で大久的にデモをや 


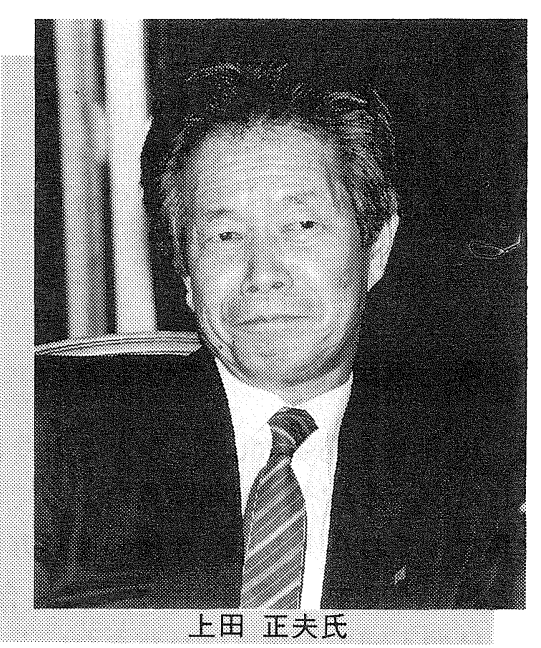

られたし，専門家の質疑応答でかなり JICSTの 仕事の中身まで突っ込んだ質問がありましたか ら, 外国からの要求はさらに強くなるでしょう。 しかしそのイギリスの会議でも，日本の現状はよ く知られていない。日本はそんなところまでやっ ているのかというのが向こうの人たちの印象で す。JICST とか文部省の学術情報センターとか, あるいは民間のデータベースの業者がそこまでや っているということを初めて知ったという人が多 いわけです。そういう意味で言うと, 日本国内で

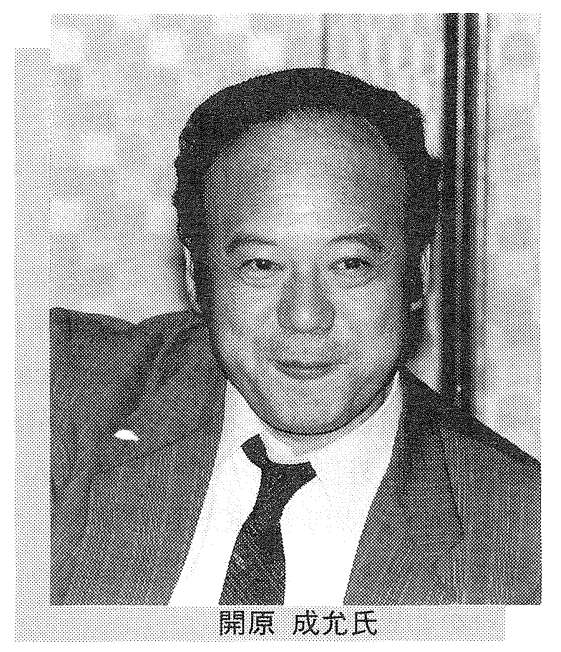

発生している情報をもっと完全にカバーしてほし いという期待が一つあります。

開原 三輪先生のお話に出ました，日本の情報 を海外へ出すということは非常に重要になると思 います。私もよく外国のいろんなところで，日本 の情報はわからないという話を聞きます。また， 10 年後に機械翻訳がどのぐらいまで役に立つか というのが大変興味のあるところだと思うんで す。

私自身もちょっと興味があって，まず辞書がな いと話にならないというわけで，今医学関係の機 械翻訳用の辞書をつくっています。これはもう間 もなくできるんですが，その経験からすると，技 術系のものだとあと 10 年でできるのではないか という感じもしますね。そうなってくると，国際 化という面ではやはり質的な変化が起こってくる かもしれません。

宮川その場合，機械翻訳に対する期待は非常 に高いわけですが，しかし，これはそれぞれの学 問の分野がございますので，今開原先生がおっし やったように分野別にいいディクショナリーとそ れを使っての機械翻訳のノウハウが蓄積されてい くということがまず第 1 だと思うんです。

もう一つ, 今度のイギリスの会議で出たのは, 翻訳は最終的にはエンドユーザであるアメリカや ヨーロッパの責任だっていうんです。これは今度 初めて私も聞いたんですが，みんなが言っていま した。基本的な部分は日本人にやってもらう必要 はない。日本人にやってほしいのは二次情報だと。 つまりアブストラクトですね。非常に包括的な書 誌情報とそれに対応するアブストラクトを完全に 集めて提供してほしい。スクリーニングはエンド ユーザがやるんだ。日本人がこういう情報はアメ リカ人には関心があるだろうと思ってスクリーニ ングをして英語に直すというのは間違いだという 話なんです。

逆のことを考えれば理解しやすいですね。アメ リカ人がこれは日本人に向くだろうと思って日本 語にして持ってきた情報をお読みになりますか。 読まないですよ。もとの英語のものを読みます。 
それと同じでここちらでこれとこれを選んで，こ れを英語の二次情報にして出そうというのはだめ なんです，基本的に。

菊池 何でもやれということですか。

宮川 条件は同じでないといけないんです。イ コールフッティングで。東京にいて，例えば今は 外国為替市場と株が每日変動していますから, 毎 朝と毎夕，「ニューヨークタイムズ」を検索してい ます。そうすると, 今日, つまり昨日の朝刊が出 ているんですよ。それでは「朝日新聞」をワシン トンで検索できるかといったらできないでしょ？ 日経テレコンがあるだけです。それは彼らにとっ て基本的に条件が違うんですよ。

そうすると, 書誌情報については日本語の書誌 情報が完全に外国でも利用できて，基本的には日 本語でもいいんだけれども，できれば二次情報の 部分は少なくとも最低限機械翻訳で英語にする。 フルテキストを機械翻訳で英語にするのは大変で す。しかし，二次情報の機械翻訳は分野別にはや はり進めるべきだし，それによって日本にいる人 たちと外国にいる人たちが同じ条件でスクリーニ ングができるようにすべきじゃないかと思いま す。

私どもの推定では，特許情報を入れますと，日 本で発生する科学技術情報のシェアは世界の 20 から $25 \%$ の間ですね。特許は非常に大きいんです が，これを除いてもアメリカに次いで，約 1 割強 です。そういう意味で，三輪先生がおっしやった ようにJICST は日本国内で発生する科学技術情 報をとにかく完全にカバーし，それが少なくとも 国内と同じ条件で外国からもアクセスできるよう な状況をつくるべきだと思います。それをやらな いと非常に大きなフリクションが起きる可能性が あります。

三輪 どこに何があるかということがわかれば いいということですか。

宮川 どこにどういうものがあって，どういう 人がいて，どういう論文に対してはどういう引用 がされていてということがわかればいい......

三輪じゃあ,翻訳は二の次ということですか。

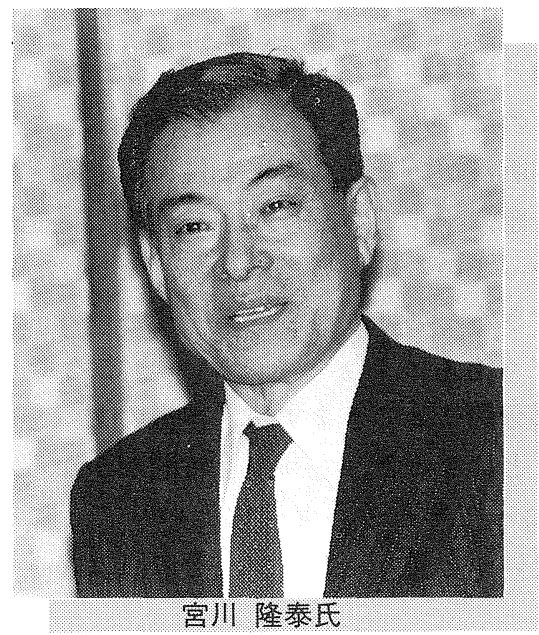

まあ，あればなおいいけども…といううわけです かね。

宮川いや，二の次じやないんです。翻訳は最 後の目的なんですが，翻訳まで日本人にやれとい うのは間違っているという議論でした。

菊池 筋としてはそうでしょうね。

宮川 連中が言うんですから。非常に強く言い ましたよそれは。

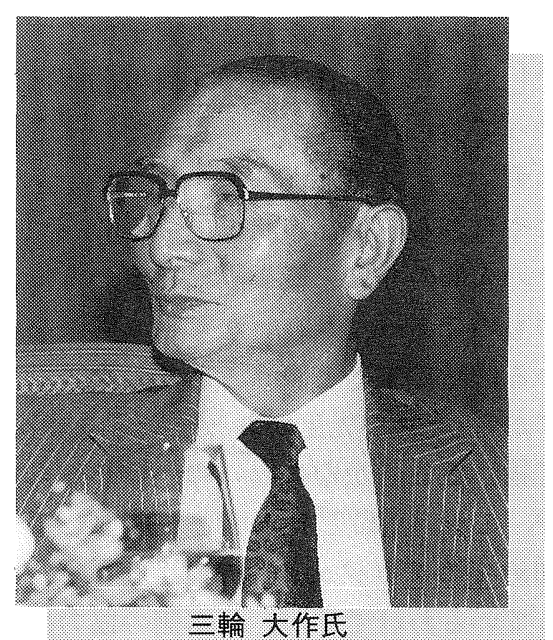




\section{機械翻訳の基礎はいい翻訳辞書}

三輪 機械翻訳の問題ですが，私が多少疑義が あったのは，昭和 33 年に電気試験所に，ヤマトと いう翻訳機があったんですよ。和田さんという人 が一所䀣命やっていました。最近また電総研で研 究をやっているのを見ましたが，確かにできるこ とはできるんだけれども，実用化ということにな るとどうももうちよっとというところでしょう ね。部分的にはできますね。本当の文章をやると いうことになると，毛う少し時間がかかる，あと 10 年たってそろそろ実用化ということになるん じやないかと思うんですが，その点はどうでしょ うか。

宮川 現在ヨーロッパ経済共同体, EC 委員会 の中に多言語政策局というのがあります。EC は 決定事項や条文をすぐに翻訳しなければいけませ んし，言葉の構造や文法が似ていますから機械翻 訳をやっているわけです。EC Japan Info という 日本科学技術情報に関するプロジェクトが今動い ていまして，この 10 月で終わる 1 年間に 5800 の 日本語の抄録を機械翻訳にかけたんです。これは 日本側がやっています。

この 5800 はマスタープロファイルで 25 の主題 分野に分かれております。その発生量はばらばら なんですが，EC 側に質問したんです。「翻訳の質 はどうか」と。そうしたら「大変結構です」とい う答でした。一方，日本側に「機械翻訳はどのよ うにやっておられますか」ときいたら「これは， プリエディティングとポストエディティングを徹 底的にやらざるを得ない状況にある」，そして「現 在はその人間の介入を最小限にとどめるにはどの 程度のものであったらいいかという実験を積み重 るている段階です」ということでした。

ですから，それが先生が扔つしやるように 10 年 たって物になるのかならないのかはわからないん ですが，これは EC と日本側とが協力してやって いる初めてのプロジェクトで, $100 \% \mathrm{EC}$ の予算 でやっているわけですが，日本側の協力機関はど の程度のプリエディティングとポストエディティ
ングが必要かというレベルを計測しているという のが現状です。

三輪 新聞にJICSTが機械翻訳をやるという 話が出ていましたね。

菊池そうです。今までJICSTの話が幾つか 出てきましたので，この際釈明をさせていただき ますが，一つは国際化に対する対応でございます。 宮川さんが言われたように，外国に対して日本の 国内の情報を紹介する，これはやはり非常に重要 な一つの柱ですから, 今後かなり力を入れてやっ ていこうと思っています。しかし，それだからと いって，本来の使命は日本国内に対する情報の提 供、サービスですから、こちらもなおざりにする わけにはいきません。ですから，今後はもう一本 新しい柱がつけ加わったとご理解いただいた方が いいと思います。

それからもう一つ，今の翻訳の問題ですが，こ れは開原先生が言われたように，今すぐはともか くとして，もう少したてば，科学技術分野に限定 すればかなりできるようになると思います。その 際, 前編集と後編集の問題は必ず条件としてつけ 加わります。完全翻訳は不可能ですから。それを 今言われたようにどのレベルでどこまでやるかと いうのはJICSTでは来年の課題なんです。

それともう一つ，何といってもいい翻訳辞書を

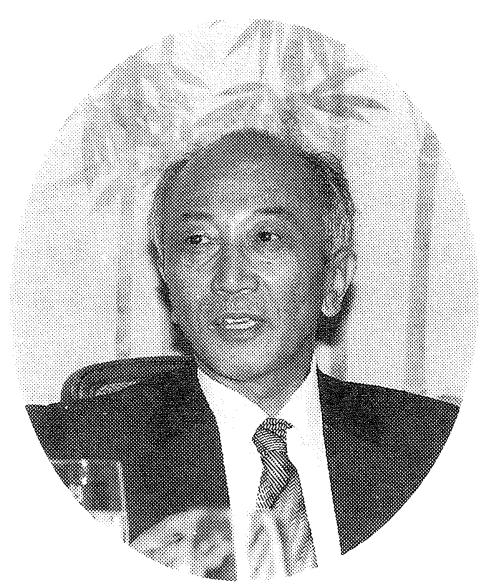

菊池 常務理事 
つくらないとだめなんです。これは言うなれば非 常に地味で, 多大の労力の必要な, 一見あまり楽 しくない仕事です。しかし，そういうものがない と実際には動きませんね。ですから，その辞書づ くりにもう少し一所懸命にならないと, ほんとの 意味での実用化にはならないんじやないかと思い ます。文法をどうする，こうするというのは随分 いろんな人が今まで研究してきていますから，あ る先生はもうそろそろ限界だとおっしやっていま す。

その先生は，「AIがそう簡単にすぐ使えるよう になるとは思之ない，意味を徹底的に分析して追 求していく方向があるけれども，それもここ 4 年 や 5 年でどうなるものでもない。それよりもいい 辞書をつくる方が一番手っ取り早い」とおっしや つています。むずかしいものは何でもとにかく辞 書に入れちゃうという方針なんです。極端に言之 ば文章を入れてしまえばいいわけですからね。

三輪 その辞書は基盤技術研究促進センターで 相当大仕掛けにやっているんでしょう。JICSTで も電総研でもやっているじやないですか。

菊池こちらでもつくっていますし, 医学の方 は開原先生の方でつくっておられますが，いずれ 売ってくださるという話ですから，楽しみにして 待っているんですよ(笑い)。

開原 ほんと，大変ですね。二十数万語の辞書 をつくったんです。もうフーフー言ってます。

菊池それだけにやはり価值がありますね。

\section{翻訳辞書作りも国際化が必要}

宮川 ただ，そのときに，私は専門でないので あまりよくわからないんですが，機械翻訳の辞書 を日本人だけでつくっていいんでしょうか。とい うのはそれ以前の普通の, 例之ばドイツ語と日本 語, フランス語と日本語, 日本語と英語の辞書と かいうのはほとんど日本人がつくっているんで す, 今までは。しかし，それについてやっぱり疑 問が出ていましたね。辞書というものは両方の国 から出ていってつくらなきやいけないんじやない
かと。

菊池まあ，それが理想でしょうね。

宮川之え。それで，これは GIDの東京事務所

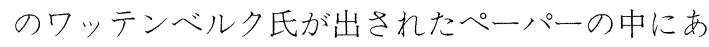
りましたが，日本語とドイツ語の間の辞書と，い ろんなターミノロジーの用語集，グロッサリーな どが 240 種現存していることが確認されている。 ところがそのうちドイツ人がつくったもの，ドイ ツのイニシアチブでつくられたものは三つしかな い。残りはみんな日本人がつくっている。つまり, ドイツのそれぞれの分野の文献，いろんな科学技 術や文化に関するドイツ語の文献を読むために， これまでは日本がつくっているんですよ。ドイツ から技術を導入するために日本側がつくってい る。ところが日本のことを見るためにドイツ側が つくったものは今まであまりなかった。こういう 状態でよろしいのかということをドイツの問題と して提起されていました。

そのときに，関連の質問で，やはり辞書をつく るときは両方の側からやるべきなのではないのか とほかの大学の先生がおっしゃっていました。こ の時, 日本の $\mathrm{A}$ 機関， B 機関， C 機関が各々の予 算でバラバラにつくっているというのは間違って いると言われているような印象を持ちました。だ から，これも国際化の一つなんですが，辞書をつ くるときに日本人だけでつくるというスタンスで いいのかなというのは, 問題として存在すると思 います。

開原 ただ，物ができていくという裏にはニー ズがあると思うんです。二百幾つのうち三つだと いうのは結局ニーズがそのまま反映しているんじ やないですかね。

\section{宮川そうです。}

開原ですから，それはいいか悪いかの問題と いうよりは，これから日本の情報が海外で要求さ れるようになってくると自然にその比率がまた逆 になってくるという性質の問題じやないかという 感じもします。

菊池 ニーズの結果がそういう一つの形として あらわれているんでしょうね。 
宮川そうすると，外国へ出すためのものだっ たら，向こう側にニーズがあるわけですから，今 度はそっちも引っ張り込まないといけないという ことがあるかもしれません。

\section{世界に通用する $\mathrm{DB}$ を}

開原 それは確かにそうだと思いますね。 この問題は，データベースについても同じじや ないかという感じがします。よく，データベース は外国でつくったものを日本がどんどん利用する だけで，日本でつくったものが今までほとんどな いと言われてきた。さっきのお話を伺うと，日本 でも随分データベースができてきたみたいです が, これから先の 10 年, この日本のデータベース が外国と同じぐらい，はたしてつくられるように なるのかどうか。その辺の予想はどうでしょうね。

上田 先生のおっしゃるのは，内容とかいろい ろな問題があるでしょうが，外国で使われるよう なデータベースが日本でも作れないかということ でする。

開原一つは，日本の情報についてのものは多 分外国でも使われるようになるかもしれません が，それはさっき言った翻訳をつけ加えないと， そのままでは向こうじゃ使わないでしょう。それ 以外にも日本のデータベースづくりの基盤がどれ ぐらいできてきているかという問題でしょうね。

上田 ある分野の情報というのは，相当使われ るんじゃないでしょうかね。少なくとも科学技術 のものは現在でも非常にグレードの高いものがで きているだろうと思うんです。ただ，宮川さんが 指摘されたように，それを外国にどういうふうに 売っていくかですね。今までは言葉の壁があると 言われていたけれども，機械翻訳で少なくとも抄 録だけでもわかるようにすることが必要でしょう ね。日本にはこういうものがあるんだということ 自体がまず知られていないんじゃないでしょうか。

情報化社会ということで書かれたものがたくさ んあり，各役所がみんな書いて出してますが，そ の中でも，国際化というと向こうから入ってくる
ものだけを考えているようで，日本の情報化で得 られたものを海外にどうやって知らせるかという ところが欠落している。だから，今話題になりま した機械翻訳のシステム自体については，京大が やっている，どこがやっている，そして，そこで 使う辞書はどうしているかとか，データベースに はこういうものがあるよということを，例えば JICSTなりから世界に知らせるといった，国際化 のための情報のインフラみたいなものが，そこは 全部民間任せでいいのか，どうもその議論が欠け てる。しかし，政府にある程度しょってもらわな いといけないような気がするんですね。

宮川 昭和 57 年からデータベース台帳ができ ました。台帳的なものが何もないので，まず，そ れをつくらなけりやいけないんじやないかという ことで，昭和 55 年から研究をやって 57 年につく ったんです。私も最初から委員でしたが，現在で は，一番新しい年次で言いますと，国内でつくら れている各種の数值および文字系のデータベース は約 300 です。世界全体の商用データベースは約 3000 ですから，すでに 1 割はあるんですよ。ただ， 現在，その中で外国にオンラインもしくはオフラ インでサービスを始めたデータベースは JOIS も 含めて 28 なんです。しかもそれはすべてここ1 〜 2 年の間に始まったばかりですね。現在計画中 のものも幾つかありますが，その程度です。

それから，現在つくられている 300 のデータべ 一スこれには AMEDASのようなものまで全部 入っていますが，それが多いか少ないかはともか くとして，その全体のリストが英語になって外国 へ出されているかというと，それもないんです。 外国の，たとえばアメリカやイギリスのデータべ 一スのディレクトリーに入っている日本のデータ ベースもありますが，それには 300 も入っていな いんですよ。だから，今度イギリスで 300 もある という話をしましたら，驚かれまして「そんなに あるのか」といわれました。まずそういうことが 知らされていないという問題があると思います。

それからもう一つは，外国にあって日本の国内 にはないデータベースの問題です。これは幾つか 
ありまして,一つは博士論文のデータベースです。 アメリカにはあります。日本は学術情報センター でつい最近始まったばかりのところです。それか ら，いわゆるテクニカルレポート。これが今まで はなかったんですけれども，JICST が 59 年から JPUB を始妉。それが今 1 万レコードを超えま した。

ただ，日本国内で発生していると思われるテク ニカルレポートは年間約 1 万ぐらいあるわけで す。R\&Dの支出額とテクニカルレポートの発生 量との相関をとってみますと，日本国内では年間 1 万からもうちょっと多いくらいのテクニカルレ ポートが発生しているはずなんですが, JICSTが カバーしておられるのはそのごく一部です。あと は出てこないので，これは何だと言われているわ けですね。

それから, 例えば工業規格, 農業規格, それか ら業者の規格, 要するにスタンダードがまだデー タベースになっていませんね。実験中です。です から, 日本の工業規格 JIS 規格のもとのものは外 からアクセスできないんですよ。

それから，これは我々の分野ですけれども，経 済学の論文のデータベースは，冊子体ではありま すし，部分的にはありますが，包括的なものはあ りません。日本人が外国の学会誌へコントリビュ 一トしたものは外国にあります。

そういったものが，開原先生がおっしやるよう に，はたしてちゃんとつくれるのかということに なりますと，これはなかなかその予算から体制か ら始まって大変だろうなという印象がございま す。ただ，外からの圧力がどんどん加わってきま すから，10 年間こういう圧力を加之続けられた ら，何か少しはできるのかなという感じもないで はないんですが，よくわかりません。

\section{質のいい DB があればお金を使うか}

開原 最初に三輪さんから，こういう分野は一 般の人々の意識がかなり変わってこないといけな いという話がありましたね。日本でデータベース
が育たなかったのは，日本人の中にそういう情報 を有料で手に入れるという社会慣習がなかったか らじやないかと言う人もいますが，それがこれか らの 10 年の間に著しく変わっていくのかどうな のか，僕はそこが興味のあるところです。

もし，お金を出しても質のいい情報を手に入れ たいという意識が急速に高まれば，恐らく日本の データベースもひとりでに育ってくるだろうとい う気がするし，もしそうでなければ日本のデータ ベースはポシャッちゃうという感じもするんです が, そこの意識の変化は, 過去を見ると, 変わっ ていますかね。

菊池 鶏と卵みたいな関係があるような気もし ますね。つまり，質のいい，使いやすいデータべ 一スが豊富にあれば金を払って使おうという人が どんどんふえてくるでしょうし……

開原 今まではなかったから使わなかった。

菊池そういうものがいかに有力な手段である か，何もわからないし知らないわけですね。アメ リカあたりでは各種の医療関係のデータベースが そろっていて，それは必ずしもお医者さんだけが 使っているんじやないという話も聞きます。

上田その医療関係のことは開原先生に聞かな いとよくわからないんですが，個人的なことで恐 縮ですが，この夏にニューヨークで死んだジャー ナリスト千葉敦子さんと長く記者少ブで一緒に いたわけです。彼女が駆け出しのときに一緒にい たもので，仲よくしていました。ちょうど彼女が 初めて発病したのは昭和 56 年じやないかと思い ますが，そのがんとの闘病記を「文藝春秋」に書 いていました。たまたま，私は広島に転勤してお りましたが，転勤してすぐ広島大学の病院に入院 したんです。毎日毎日検査が続くので，「何だ」と 言ったら，「おまえは腸に腫瘍があるから，それを 切る」という話なんですね。

そのとき，腫瘍とがんはよく似てるということ はわかっていたけれども，どう違うのかはわから なかったし，毎日やっている検査がどうして必要 なのかよくわからないわけですね。たまたま彼女 の䦔病記を買ってきて読んだら，彼女が乳がんを 
切る前にやっている検査を私も全部受けているん です。「あれ，おれはがんかな」と思いまして，「先 生，私はがんですか。どうぞ，はっきりおっしや ってください」と言ったら,「おまえ, 幾ら医学が 発達したからって, 細胞をとってきて培養してみ なきや，上からのぞいただけじや，がんかどうか わからないんだ」ということでした。まあ，がん だとおっしゃりたくなかったのか，それはわかり ませんがね。切ってみなきやわからない(笑い)。 だから，日本では「まあどっちでもいいや。とに かく先生に任しちゃえ」という感じですね。

ところが, 彼女はニューヨークへ行ったんです。 「朝日ジャーナル」にもいろいろレポートを書きま したし，「読売新聞」には毎週 1 回連載していまし た。彼女は経済, 財政の分野で世界に通用するジ ヤーナリストだと言われていて，一生懸命人にも 会うけど，自分で疑問に思ったことは放っておか ないわけです。それは取材でも生活態度でもそう です。だから，自分の乳がんを治すために，乳が んがぞういう状態であるかを的確に知るには日本 よりもニューヨークがいいというので，彼女はニ ユーヨークに行ったわけですね。

そして図書館へ行って乳がんに関するレポート を毎週のように調べる。罒書館へ行くと，アメリ カでは乳がんの先生はだれがいちばんよくてどこ の病院がいいかとか，いろんなことがわかるし， パソコンを駆使すればいちばん新しい乳がんの病 歴としてどういうものが発表されたかということ が簡単に手に入ると。簡単に手に入るのはデー夕 ベースが整備されているからだというわけです ね。まあ，そこまではわかるんですが，じやあア メリカの人は病気になったらみんなそうしている のかなという疑問もあるんです。教育のレベルを 考えたって，そんなに利用していないという気も するし…..

\section{より多くの国家援助を}

三輪 突然話を変えますが, JICST をつくると きに情報センター法というのを国会に出したんで
す。その第 1 条には，情報センターは情報活動の 中枢機関であって, 迅速・的確に情報を提供しな ければいけないということがありました。どこへ 提供するかというと, そのときには我々は, 外国 なんてことは全然考えなかった。国内にそんなに レベルの高いものができるとは思わなかったか ら，とにかく外国のものを集めて，速くその抄録 をつくって日本の企業に出すということしか考え ていなかったんです。

だから, JICSTが英訳して出すという時代にな ったとき，センター法との兼ね合いでどうかなと いう話も聞いたんです。日本の国内以外に出して はいけないとは書いていないから，それは提供し ていいわけですが，その当時はそうしか考えられ ないくらい,レベルが低かったでしょうね。戦後, 日本はトラックをつくってもいい, バスもつくっ てもいい，けれども普通車はだめだといって。た しか昭和 30 年まではだめだった。それで普通車の 生産が遅れたように, 外国に対しての提供も, 先 ほどお話があったように，多少そういうことがな いとは言えないと思うんですよ。

それから，もう一つ，JICSTがこんなに大きく なって，これからはいろんな情報の処理を，今の 55 万件からなるべく 100 万件に近づけようとい う計画があると聞いていますが，そういう要望に 答えていくためには，ますます国の援助が必要な んです。

これは営利を目的とする機関じやなく, 初めか ら「もうからないよ。だけど，ためになるものを つくれ」ということで特殊法人にしたわけで，今 でも半分以上は国の出資金や補助金をもらってい て，それで大型のコンピュータを買うとか，ある いは情報員の育成に充てたり，給料を払ったりし ているんです。そして昭和 60 年, 61 年, 62 年は, その規模がふえていますが，収入も急激に上がっ ているわけです。

つまり, 国の出資が多ければ多いほど業績も上 がるんです。ですから，これから 10 年の間に, 国 に「もういい」と言われては困る。今まで以上に 出資, 投資をしてもらわないことには, 日本の使 
命がはたされないと思うんですよ。これは，菊池 常務を初めその他役員諸公の大変なご努力を要す ることですが。

JICSTをつくったときは，鳩山威一郎さんが主 計官でしたが，10 年の計画を出したときに「補助 金はゼ口にはなりませんよ。いつまでたっても国 の援助は要りますよ」ということは言ってあるん です。「多少は減るでしょう」とは言ったんですが， 実際には減らない。どんどんふやしてもらわない といけない。今お話があったように，欧米からの 要望が大きいですから，国策としてやらないと， 貿易摩擦にも影響があるわけでしょう。そういう ものをどんどん出しておれば，多少でも日本の誠 意を認めてもらえるんじやないかなと思うんで す。

宮川 国がそれだけのお金を出して国民の意識 がどう変わったかというか，どれだけ普及したか という話ですが，データベースを使う人が持って いる暗証番号，パスワードの合計は，重複があり ますから正確にはわかりませんが，日本全国で大 体 4 万から 5 万ぐらいの間だろうと思います。そ のうち, JICST が五, 六千で，1割くらい持って いらっしゃる。では, 同じものがアメリカではど のくらいだろうかといいますと、これもまた計算 のしようがいろいろありますが，大体 120 万です ね。向こうは人口が 2 億いるんですが， 2 億で 100 万ですから 200 人に一つ持っているわけです。日 本は 1 億人で 5 万ですから， 2000 人に一つです。 つまり，10 対 1 ぐらいの差があるわけです。

そうすると，その原因は，PRが足りないのか， あるいは開原先生がおっしやったように日本はそ ういうものに金を払う傾向がまだないからなの か, 教育が足りないのか, そういう問題が一つあ ります。私も闘病記を読んで，千葉敦子さんがデ ータベースの検索をオンラインでやり，それをお 読みになっているのを読んだのですが，それは恐 らく 100 万対 5 万の差だろうと思うんです。ただ 日本とアメリカの経済力の比からいきますと，10 対 1 というのはバランスがとれていないんじゃな いかと思います。
よく，それは日本人の国民性だと言いますが， 国民性というのは経済学のタームじやないんで す。「国民性という固有のものがあって，それが通 常の経済原則の貫徹を妨げている」ということを 経済学は非常に認めたがらないし，私もそういう ものがあるとはあまり思いません。日本の産業は, まあ違う点もありますが，「30 年前のアメリカの 自動車はこうだった」とかいうように，アメリカ でやっていることをまねしてきたわけですから ね。

そういう意味では，パスワードホルダーの数で は, 正確な数字ではありませんが 10 対 1 くらいの 差が今あることは間違いないことです。しかし， それがJICSTの費用に対する国の資金の投入が 子えればどんどん子えていくのかどうか。

上田 今おっしゃった 5 万人には, NECのC\& Cの会員とか，ああいうものは入っているんでし ようか。会員数は約 3 万人と言うんですね。あれ は，データベースの会員とかただパソコン通信の 会員とかいうよjに，グレードがいろいろですか ら，どこで切っているのかはわかりませんが。 ただ，それを大ざっぱに割り切ると，とにかく NECのパソコンを使って，データベースを使わ ないまでもパソコン通信みたいに友達と云々とい う連中が 3 万人いる。それから，ほかのパソコン メーカの会員もあまり多くはないらしいけど，い る。

そういうのを見てますと,これから先の 10 年間 は，データベースや情報にお金を使うことをいと わない人たちが多くなるだろうと思うんですよ。 だから，もし「データベースをうんと使え」とか 「情報化のハードなりシステムをうんと使わせた い」と思うんだったら，僕は「経済白書」でも何 でも,パソコンを持っている人にアンケートして, おまえの収入は幾らで，ネット料に，電話料も当 然大るわけだけど，幾らくらい払っているかを聞 いて，「情報化支出」を出して，それを人間のステ ータスをくすぐるような言い方で発表したらいい と思うんですよ。つまり，「エンゲル係数の高いや つは所得の低いやつだ」というようなエンゲル係 
数と逆の言い方で, 「情報化支出の高い人がナウイ 人なんだ」という分析をやったら。そういうのに 日本人は割合弱いから，使う人は子えるような気 がするんですね。

ただ，その場合に，さっき千葉敦子さんの例で 意識の問題だと申しましたが，そんなに患者がい ろんなことを知っちやったら，お医者さんはどう するんだろうな(笑い)という気がするんですよ ね。

\section{論文を DB へ入れないと研究者じゃない}

開原 それはアメリカと日本の医療事情の差で すね。ただ，千葉さんが使っていたのは，患者向 けにつくられたデータベースではないですね。あ くまでも医者向けにつくられたデータベースで す。

\section{上田之え，そのようですね。}

開原 アメリカではそういうものについては, 非常におもしろいデータベースがいっぱいあっ て, 国立がん研究所はがんの最先端の治療方法を データベースにして全医師に提供しているし，が んの専門医が全国のどこにいるかというようなデ 一タベースもあるんですよ。これは今, 日本から もアクセスできます。やはり，そういうものをつ くっていこうというモチベーションが, 日本はま だ弱いような気がします。

日本ではJICST みたいに，専門の機関で国か
らお金をもらって「やりなさい」と言われるとや る。ところが，向こうの国立がん研究所は，デー タベースをつくれとだれに言われたわけでもない と思うけれども，研究成果はそういう形にして国 民に還元しなきやいけないと自発的に思って，そ ういうデータベースをつくって提供しているわけ です。別に日本の国立がんセンターの悪口を言う わけじゃないけど，それじゃがんセンターがそう いうデータベースをつくって，例えばJICST と タイアップして提供しようというようなムードが 出てくるかというと，まだ日本ではちょっとない ですね。

宮川それは研究者の姿勢の問題で, アメリカ ではよく「パブリッシュ・オア・ペリッシュ」と 言いますでしょう。商務省の NTIS のデータベー スに入力するための一般向けマニュアルには「あ なたは自分で発表された論文なりレポートをここ へお入れにならないと，損ですよ。自分で持って いるだけ，あるいは発表しただけではあなたのや ったことは知られませんよ。ここへ入れれば，ち やんとアクセション番号がついて，この人はこう いう仕事をしたということがパブリックなものに なる。だから，お入れになることをお勧めします。 費用は幾らです」というようなこと書いてありま 于。

開原、今のは「お金を払ってでもデータベース に入れてもらいたい」という話ですよね。

宮川そうなんです。ちゃんと料金をとってい

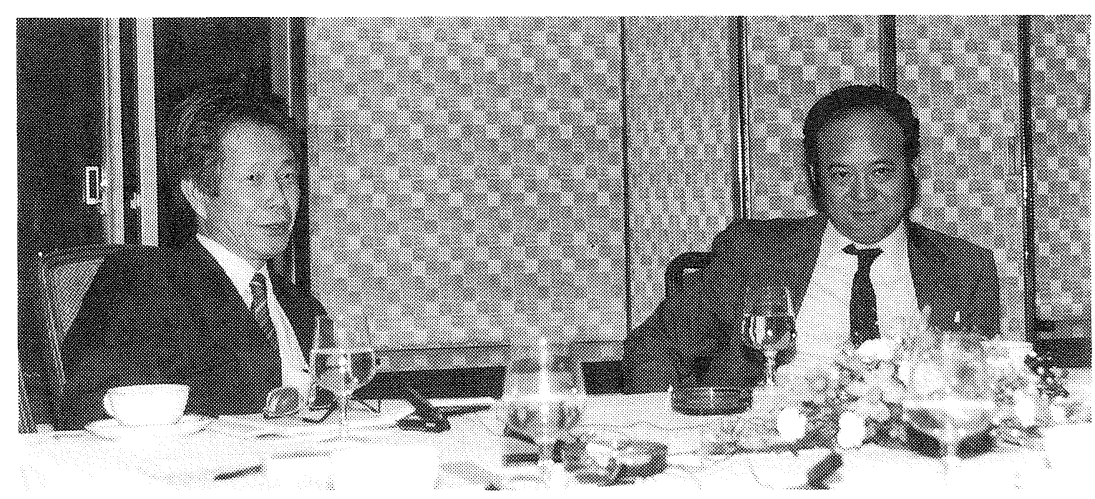


るんです。ドキュメントシートがついていまして 「これに書いて何部か添えてお金を持ってきなさ い。そうしないと，あななは研究者としては通用 しませんよ」と書いてある(笑い)。そうすると， みんなそうする。

開原 だから，JICSTなんてうまくやると，二 重にお金をとれる(笑い)。

菊池それはいいアイデアですね(笑い)。

\section{質か量か，むずかしい対応}

宮川 その話が出ましたので，もう一つ言いま すと，アメリカのやり方で私が気がついたのは， 入力の仕方についてなんですね。JICSTさんは情 報員がいて，全部自力でしておられますね。

実は，この間のイギリスの会議で「JICSTの抄 録の品質管理はどうしているんですか」という質 問が出ました。それが向こうは非常に気になって いるんです。抄録が英語になればなるほど，これ は問題になります。

例えばNTISのデータベースでは，エナジーは エネルギー省, それから石炭は内務省, 住宅は厚 生省でつくったサブファイルを入れて統合してい る。もちろん，商務省のものは自分でつくります。 だけど，ちょっと分野を離れたところのものは， みんなそれぞれが分散的に同一の標準で処理した ものを持ってきてマージする。そういう形になっ ています。
菊池こちらもうちで抄録をつくっているわけ ではなくて,外部に大体 4000 人くらいの専門家を 抱えていまして，抄録は各分野の専門家の人につ くってもらっていますから，そういう意味では JICSTの今の体制がその観点から必ずしも間違 っているという言い方はできないと思うんです が。

宮川 ただ，JICSTの情報員はそれぞれの専門 分野におられますけど，アメリカでは，そこの情 報員じゃなくてみんな別のそれぞれの機関がやっ たものを同じ基準でマージしているんです。

菊池そういう考え方が一概に悪いとは申しま せんが，全体としてのクォリティーをそろえるの が非常に難しい。クォリティーがばらつく可能性 が逆にありますね。

宮川之え。それは必ずおっしやるんです。ア メリカでもその問題があったんです。だけど，そ こを突破しないと量は拡大しないし，最終的には それぞれの専門分野のクォリティーはそろわない と思いますね。

菊池 それともう一つの問題として, JICSTが 全分野を一括してやるやり方に対して，専門別に やったらどうかという意見があるんです。ところ が，実際問題として今，先端技術と言われている バイオテクノロジーにしても新素材にしても，そ の専門を特定できないんですね。まさにそれが今 の問題点だとすれば，伝統的に化学，物理，機械 と分けたデータベースでは，今のユーザのニーズ

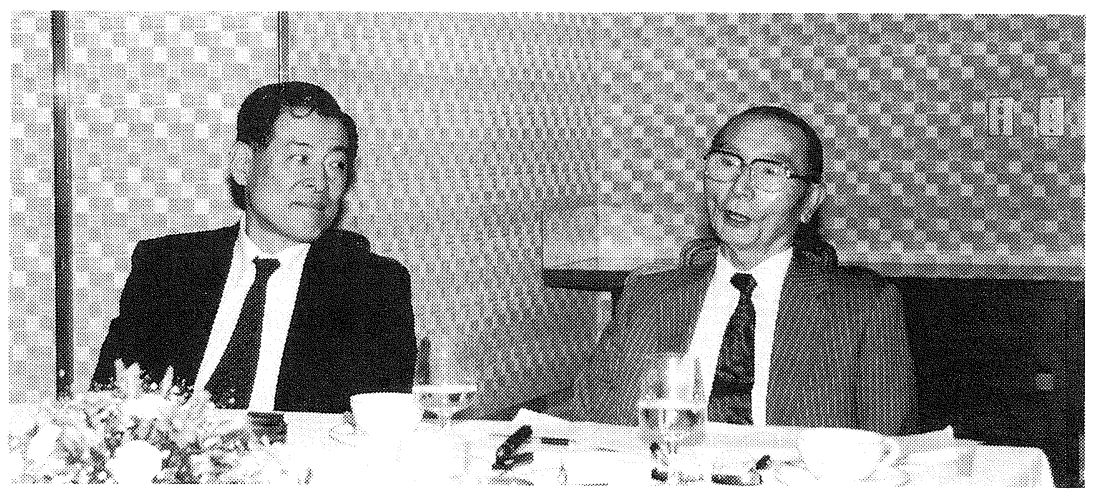


には対応し切れないと思うんです。むしろ，そう いうものを取り払って全体としてまとめるいき方 の方が, 10 年後に威力を発揮するような時期に来 てると思うので，いろいろ批判はありますが，頑 強に今のやり方に固執しているわけです (笑い)。

宮川ただ，こういうことがありますね。コン ビナートの環境保安の問題で，その関係の論文を 専門的にフォローしているグループがあって,「と てもお金がかかってかなわないから，JICSTに乗 りかえたらどうか。ただし，カバー率の実験をし てみよう」ということで，そのグループが 1 年だ か何か月だか知りませんが，テストをしたわけで す。

菊池そしたら，荒過ぎると。

宮川之之。そのグループはコンビナート保安 の専門家ですから，細かいものをずっととってい て,メンバーに送っている。ところが，それをや めて JICSTにしよjとしたらそういう問題があ る。

菊池 それは今すぐは無理でしょう。

宮川ですから，このコンビナートの保安とい うのが適当な例かどうかよくわかりませんが，こ の問題についてはそこでつくったものを JICST へ入れる。むしろそれを指導してJICSTのクォ リティーにまで引き上げて入れる。そういうやり 方があるんじやないかと思います。

菊池 それは考えられますね。

宮川そうすれば，そのグループは，その分野 の専門家ばかりですからね。今は恐らく JICST からみれば，そこでつくったものはレベルの低い ものかもしれませんが。そういう問題はほかにも あると思います。

菊池あります。

宮川 恐らくこれから 10 年の間に, 日本のデー 夕ベースをつくるときのつくり方の問題として, この問題はコンスタントに出てくると思います。

菊池 ですから，宮川先生がいみじくもおっし やったように，量的にどうするかという問題と， どれだけ，単に質の問題じやなくて，荒っぽくじ やなくきめ細かくそれぞれに対応するかという問
題の雨面を考えなければいけませんね。

\section{$J I C S T$ に必要な R \& D 部門}

三輪 専門センターは方々にあるんだから, 総 合センターとしての使命をはたすには，今言った ようにJICSTの職員が相当の実力を持ってい て，また JICST 自体が全部そういうのを標準化 していくという役割が大きいと思うんですよ。た だ，残念なことに，特殊法人というのは，人間の 増加がないんです。件数はどんどんふやしている けれども，大蔵省は人間をつけないんです。

それはやむを得ないとしても，人間がやるんで すから，どんなに機械化しても，チェックだとか シソーラスの改定だとかは，5年に一回ぐらい必 要になってきますが，そういうのは，若い人がど んどん入ってきて，活気にあふれた仕事でないと いけない。だんだん老化しては困る。その辺で， JICST には, 気の毒というか, 非常に特殊法人と してのやりにくい面があるんですよ。

開原 僕も今の三輪先生の扔つしやったことを 感じますね。医学の分野では，こういうことをや っているアメリカの機関ですと, National Libraly of Medicine(NLM)があります。付属とし てリスターヒル・リサーチ・センターという研究 所を持っていますが，やはり NLM がやっている ことと JICSTがやっていることを比較してみる と，随分違いますね。

NLM は，一方でMEDLARS をつくって，一方 で図書館をやっている。まあ, 図書館だからそう いう面もあるんですが, あそこは研究開発的な要 素が非常に強いんです。まず一つは，新しいメデ イアの開発ですね。ですから, CD-ROM みたいな ものが出てくると，MEDLARSはCD-ROMに 入れる。また，それをコマーシャルにも提供する。 どうしてそういうことができるかというと，中に それを研究している連中がいるというのが一つじ やないかなと思う。

それから, 今一所懸命研究しているのは,レー ザーディスク, 光ディスクの応用ですね。あとも 
う一つ大きな研究テーマになっているのは, General Medical Terminologyです。いってみれば $\mathrm{MeSH}$ をもっと拡張して全体をカバーするよう なターミノロジーのシソーラスをつくるという, 大きな研究です。あ, $\mathrm{AI}$ 的な研究もやっている。

そういうふうに，NLM は単なる図書館であり 情報提供機関のようであるけれども，その裏には 絶えず 10 年先， 20 年先を見てフィードバックを かけるような研究所が付属しているんです。

ところが，JICSTの場合には，今までの話を聞 いても,メディアが将来どうなっていくかという 話があまり出ない。やはり, 従来のコンピュー夕, 端末，デー夕ベースが話のベースになるけど，ど こかに発想を変えることを絶えずJICSTに働き かけるようなグループがないといけないんじやな いか。それが 10 年後に JICSTがおくれをとらな いための一つの方法ではないかという感じがしま すね。

三輪ソビエトのVINITIにはたしか研究所 か学校みたいなのがありますね。だから, JICST 付属研究所とか研究部とかいうのが必要だね。

菊池 必要です。こういう時代になってきます と,そういう強力な研究機関を持っていませんと, ついていけないですね。いきなり研究所をつくる というわけにもいきませんので，当面は外部，例 えば開原先生とか，多くの先生方にいろんなご意 見を聞きながらどうしていくかという委員会をつ くっています。それでも何もやらないで手をこま ねいているよりは，よほどましですからね。

三輪 将来は作る必要がありますね。

宮川 私は 10 年前の NIST, もう 10 年たった んですからもう一度専門センターとナショナルセ ンターの関係を別の観点から見直して，もし日本 に例えばNLMのようなものが必要であれば，つ くる。ナショナル・アグリカルチュラル・ライブ ラリーが必要ならつくる。それから BLのドキュ メント・サプライ・センターみたいなものが必要 なら, JICSTの資料館は多少それに似たような機 能をはたしつつありますから，そういうものをつ くる。そして，その専門センターとナショナルセ
ンターの関係を研究する。要するに, 第二次 NIST が必要だと思います。

それから、今は開原先生がおつしやったように， 伝統的な大容量のホストコンピュータに磁気テー プベースで入れてオンラインでやるという形です けれども，年間 55 万件もあって，中はいろいろ分 野別になっていますから，それこそCD-ROMで とにかくファイルを分けて出して，オンラインで JICST とつながなくても JICST のファイルを国 内でも外国でも別々に使えるようにする。

溯及的検索をしないといけないとか，包括的に やらないといけないというときにはオンラインで やるけれども，そうじやなくてある特定の分野だ けのサブファイルがあればいいという場合には CD-ROM で出す。特に外国なんかはそうですよ。 だから，そういうことも必要でしょうし，いろい ろな形があり得るでしょうね。

菊池 おくればせながら CD-ROM の検討は始 めてはいます。

宮川だから, 私は基本的にはもう一度, NIST で議論されたことを別の観点でやる時期に来たん じゃないかと思うんです。

菊池、NIST は見直しが必要なことは十分に認 識しているんですよ。ただ，非常に難しい問題が いくつかあります。

宮川 科学技術庁だけでそれをやるとだめなん です。

三輪 科学技術庁は各省の研究調整をやるとこ ろですから通産も文部省も協力できる。だから， 科学技術庁が本腰を入れてもう一度 NIST 構想 を，今後 10 年，つまり 40 年目に合うように再検 討することが，私は必要だと思うんですよ。ああ いうものをつくっても予算の裏づけはあまりない んです。

宮川 情報化社会には, 日本型縦社会と矛盾す る面がありますね。情報というのは非常にホリゾ ンタルに拡散して流れていくものですので，バー ティカルな,リジッドな構造の中だけで流通して いる情報というのはあり得ない。非常に横に流れ ているわけです。だから, 過去 10 年, 例えば私な 
んかは民間ですが，この情報サービスという分野 では，官民の境界線，ディマケーションラインが 非常にはっきりしないんですね。

それから，私は産構審の情報部会のメンバーで あると同時に文部省の学術情報センターのメンバ 一ですし，しかも JICSTにもいろいろお願いを したり申し上げたりしている。だんだん，そうい うことが可能になってきたんです。昔はそんなこ とはできなかったんですよね。

菊池 そういう土䁃，基盤ができてくれば，非 常にいいと思いますね。

宮川 確かにおっしやるように，科学技術庁は 調整ができる機能をお持ちですよね。あの時点で は，科学技術庁主導で，科学技術庁傘下の問題が 中心で，ほかからの入力は強力にはなかったわけ ですが……

アメリカでは 1963 年ごろに，横断的な NTIS ができる前にワインバーグレポートを出ました ね。アメリカの政府だって縦割ですから，実際は 閉鎖的ですが,それは今後 10 年の課題の一つじや ないでしょうか。私はそう思います。

\section{CD-ROM 化は民活で}

上田 CD-ROM 化というのは，ハードの方か ら見ると，そう難しくないでしょう。

菊地 問題は，ニーズですね。いっぱいつくら ないと採算がとれない。 5 枚や 10 枚ではとても高 くなるんです。少なくとも 100 以上出ないと。で すから，これは技術の問題よりもニーズの問題で すね。

上田 ただ，100枚とか何枚とかと言う以前に， 記事データベースだって新聞社はみんなやってい るわけだけれども，あれも本当にどれだけニーズ があってやっているのかわからないわけですよ ね。ただ，幸いなことに，昔だったら入力が大変 だったけど, CTS をやったからテープに残ってい るのをシソーラスによって分類したり各社各様で やっているわけですね。

菊池それともう一つ，条件があるんですね。
アメリカの場合だと, IBM の機械に乗るようにし さえすれば売れるんですが，我が国では各社の標 準が違いますから, 個別の対応が必要となるので, そこがちょっと難しいんですよ。

開原 そこは僕はむしろ逆だと思う。JICST み たいなところこそがもっと努力して，データべー スの標準化を図るべきだったと思うんです。それ をやらなかったから今漢字の問題にしても，ある 程度の標準化はできてるのでしょうが，端末のと ころで一つ一つのやり方に対応するのは，実に大 変な話ですよね。

本当を言えば，その辺はナショナルセンターな らばもうちよっと指導性を発揮してもよかったん じやないかという感じがしますね。

三輪 それと，やっぱりスタッフをもう少し子 やして強力にしないと，今の陣容では本当に忙し くてとても手が回らないと思いますよ。

菊池 研究も含めた一種の強力なスタッフ機能 ですね。

開原もう一つ，最近は民活ばやりですから， 民間との提携をもうちょっとうまくやる方法があ るんじやないかという気がするんです。

また NLMの例を出しますが，NLM なんかは 自分でデータベースをつくるけれども，全部自分 でサービスしようなんてことは夢にも思っていな い。それをボーンと売っちやうわけですよ。それ を使って勝手にだれでもいいからサービスをしな さいと。まあ，だれでもいいというのは，言い過 ぎですけど，売るわけです。CD-ROM だって，あ る会社とコントラクトを結んで，そこへ有償で売 る。だから，実際にマーケットをやっているのは， NLM じやなくて会社ですよね。そういうことに よって実際のNLMのアクティビティ一の数倍 の影響力を持つことができる。

だから，うまくやればそういうこともできるん じやないかなという気がするんです。確かに今は CD-ROMもニーズがないかもしれないけれど も，現在会社でやっているところがないかという と、ニーズがないに甩かかわらずやっているわけ ですよ。 
菊池やってますね。あれはあまり売れていな いと思うけど，一種の先行投資でしょうね。

開原そう。先行投資。やっぱり民間企業のい いところは，そういう先行投資がフレキシブルに できるところだと思うので，そのときにもし 「JICSTのデータベースをあげるから，売ってご らんなさい」と言ったら，僕は随分それをやると ころは出てくるんじやないかなという気がするん です。

上田 開原先生が扔っしゃったことはまさにそ のとおりだと思うんです。CD-ROM 化すること は機械的にそう難しくないとおっしゃるわけです から，ニーズが幾らあるかという話はちょっと横 に置いておいて, 開原産業なり日刊工業なりが「こ の部分をやりたいんだけど」と言ったら，お金を とって(笑い)「どうぞ」とやらせておけばいいん ですよね。

開原そうそう。お金をとればいいわけです。 本当にそうだと思いまする。

上田もう一つ, 日本という国は大変おもしろ いことに，あれはどこと組んだか知りませんが，

例えば岩波とどこかが組んでやったら，その残っ たやつはウの目夕力の目で相手を捜してやるでし よう。そういう波及効果が非常に大きい。

それがもうかるかどうかはわからない。先行投 資か見栄なのかわからないけど, 新聞社でいえば 記事データベースを持ってないやつは二流かなと 思われるような雾囲気があるわけですよ。だけど， 一般の読者は記事データベースをここはやってる とか, ここはやっていないとか，そう考えていな いと思うんです。日本の企業社会は非常に競争が 激しいし，それに対応する力があるんだから，開 原先生がおつしやったように CD-ROM について は，JICSTではあまり研究されなくても，その辺 の対応策だけをきちっと考えておけばいいんじや ないかと思いますね。

\section{産業・個人・社会, 三つどもえの情報化}

宮川 JICSTについて言うと，民間との関係は
この 10 年でも随分変わったと思います。例えば日 刊工業新聞という民間の会社がおつくりになった データベースをJICST がマンウトしてサービス をしておられる。それから逆にJICST 指定の代 行検索だって数十もあるわけでしょう。10 年前に そういう議論をしたら,「いや, JICST のミッショ ンからしてそういうことはなかなか難しいんじや ないか」ということになったと思うんですよ。だ けど，10 年間の変化でそうなってきているわけ で，恐らく情報サービスの民間との関係は，やっ ぱりさらに複雑になっていくと思うんです。

ですから，JICST が本来の使命をはたすために も，そjいう民間との協力が必要になってくる分 野はあると思います。

菊池それはこちらも十分自覚して，今おっし やられたように，かなり開放してきてはいます。 この傾向は今後も続くでしょうね。一度そちらの 方向に乗り出したら, 自動的に進んでいきますよ。 一歩目が大変なんです。一歩，二歩が出れば，あ とは三歩，四歩と行けるような気がします。

まあ，それぞれの状況，いろいろなも毛のを見極 めながらやらないと混乱する可能性はありますの で，やはり一歩一歩確実にやっていこうというこ とでやってはいるつもりです。

上田 データベースにしても情報社会というの は大変お金がかかるから，やはり日本がここまで 来て世界の経済大国になったという，経済的な裏 づけに支えられているんだろうと思うんですよ。 JICSTもそうだし，民間の方もそうだし，新聞社 己そうです。だから，一番最初に大先輩がおっし やったように，補助金は減らないよということで する。逆にふえているわけですが，そういうふや せるだけの経済力が，それが税金だとしても，あ るわけですね。

これからは，そういった意味でまだまだお金が かかるだろうし……

三輪 今はやりの民間活力というか，民間企業 の活力を吸いとれというのがだいたい今の大蔵省 の方針ですよね。国だけではないよ，国と一緒に なって民間の資金も集めてやるというように，研 
究補助金なんかは今度みんな変わっちゃうんで す。だから，おっしゃるように，JICSTが中心で， 日刊工業新聞に委託研究じやないけれども，こう いうものをつくれと言えば，統一できると思う。 だけど, JICST 抜きでやるとそれはやはりぐあい 悪いだろうし，JICSTの意図に従ってというと， JICST に相当実力がないと, 民間はついていかな いんですよ。

開原 実力は随分ついたんじやないですかね。

菊池いやいや，これからですよ(笑い)。また 鉢卷きを締值してやり直さなければいけない (笑い)。

要するに, 非常に大きく分けて, 産業の情報化 の問題と, 個人の情報化の問題と, 社会の情報化 の問題の三つがあるような気がするんですね。そ の三つが交錯しながら行くんだけれども，先導し ているのはやっぱり産業でしょう。

いちばんわかりにくいのが社会システムで,こ の中には医療も入るし，教育も入るし，行政も入 る。しかしこれは，さっき開原先生も言われたよ うに，プラスの面とマイナスの面とがあってこれ をどうしたらいいのか，何がメリットか，評価の 基準があまりはっきりしない。だからそこにこそ 三輪大先輩が言われたように，国が相当金の面と かいろんな面でてこ入れしないといけない。

産業の方は，自分の会社でやった方が得だと思 うことは幾らでもやるし，ほっておいてもできま すね。また個人の方はまだまだいいと思うんです。 まあ千葉さんみたいな人もいるかもしれません が。ともかくそうやって社会システムが充実して くれば，個人が自動的に恩恵を受けるようになり ますからね。あまりごちゃごちやするとわからな くなるから，区分けして考之る。民活もいいけれ ども, 一応縄張りぐらいは決めておかないとね(笑 い)。

上田おっしゃるように，産業界はみずからも
情報をつくるかもしれないし，またJICSTの情 報なども利用している。それはNK-MEDIAを使 ってくださる毎月の時間を見たってわかるわけで すね。そのように産業界はデー夕ベースを使うこ とに非常に慣れてきているし，これからますます 情報が必要になるでしょう。データベースを使う とお金がかかるけれども，それに見合ったものが どこかで得られるということで，最後は勘定の帳 尻を合わせているんだろうと思う。その意味では 産業的な需要は潜在的にあるから，いいものをつ くっていけば，何がいいものかという評価の問題 はあるとしても，そj心配することはない。

それから，個人の方も，だれがつくるかは別で すが, こういうデータベースがあるんだ，うちに あるパソコンで使えるんだということがわかって きたら，そういう人たちが結構使い始めるでしょ うから，それも政府が云々という心配のない部分 じゃないかと思うんですね。

ですから，菊池さんがおっしやったように，結 局はまたがる社会の問題と，日本の情報をどうや って海外で使い勝手のよいものにするかというこ とに尽きちゃうんじやないでしょうか。僕はそう 思います。

菊池いろいろなお話が出てきまして，まだま だ話は尽きないのですが，時間も相当経ちました ので，非常に残念ですが，この辺で終わらせてい ただきます。

10 年後の情報社会へ向けて今，何をなすべき か，いろんな可能性等，非常に具体的なお話，あ るいは私どもにとって耳の痛いお話等ありました が，本日のお話しはあえて結論を出さずに，これ から先の社会の中，あるいはJICSTの動きの中 で確かめていきたいと思います。本日はどうも長 時間ありがとうございました。

(文責 本誌編集委員会) 